\title{
Embryo Development and Post-Hatch Performances of Kampung Chicken by in Ovo Feeding of L-Arginine
}

\author{
M. Azhara, , D. P. Rahardja ${ }^{\mathrm{b}}$, \& W. Pakiding ${ }^{\mathrm{b}}$ \\ aScience and Technology of Animal Agriculture Study Program, Graduate School, Hasanuddin University \\ ${ }^{b}$ Department of Animal Agriculture, Faculty of Animal Agriculture, Hasanuddin University \\ Jalan Perintis Kemerdekaan, Makassar 90245-Indonesia \\ (Received 13-07-2016; Reviewed 01-08-2016; Accepted 09-11-2016)
}

\begin{abstract}
The research was conducted to evaluate embryo development, post-hatch performances, and growth rate of kampung chicken treated in-ovo feeding of L-Arginine. A total of $135 \mathrm{kampung}$ chicken fertile eggs (weight 42-43 g) were used and divided into 5 treatment groups of three replications. They were placed in the semi-automatic incubator. The first group was without in-ovo feeding (negative control); the second group was in-ovo feeding of saline $0.9 \%$ (positive control); the 3 , 4 , and 5 groups were in-ovo feeding of $0.5,1.0$, and $1.5 \%$ L-Arginine, respectively. In-ovo feeding of L-Arginine were injected into albumen on day 10 of incubation period using automatic syringe in the narrow end side of egg by inserting needle through a small hole at $10 \mathrm{~mm}$ depth. After hatching, all day old chicks were placed in floor pens $(1 \times 0.5 \times 0.5 \mathrm{~m})$ accordance with the previous egg groups. The results showed that in-ovo feeding of L-Arginine increased weight and circumference of the embryo, but did not affect the length of embryo. In-ovo feeding of L-Arginine resulted in a higher body weight gain and a lower feed conversion even though feed intake was not significantly different compared to the control groups. The growth rate performance up to 6 weeks rearing increased significantly by increasing L-Arginine administration to $1.0 \%$. It can be concluded that embryo development and post-hatch performances of kampung chicken were markedly increased by in-ovo feeding of L-arginine.
\end{abstract}

Key words: embryo, in-ovo feeding, amino acid, productivity, kampung chicken

\begin{abstract}
ABSTRAK
Penelitian ini bertujuan untuk mengetahui perkembangan embrio, performa dan tingkat pertumbuhan ayam kampung setelah menetas dengan perlakuan in-ovo feeding menggunakan L-Arginine. Sebanyak 135 butir telur ayam kampung fertil (bobot 42-43 g) dimasukkan ke dalam mesin tetas semi-otomatis dan dibagi menjadi 5 kelompok perlakuan 3 ulangan. Perlakuan pertama ialah tanpa injeksi (kontrol negatif); perlakuan ke-2 diinjeksi dengan saline 0,9\% (kontrol positif); perlakuan ke-3, ke-4, dan ke-5 masing-masing diinjeksi dengan L-Arginine $0,5 \%$; $1,0 \%$; dan 1,5\%. In-ovo feeding dilakukan pada hari ke-10 inkubasi dengan injeksi ke dalam albumen menggunakan syringe otomatis dengan memasukkan jarum melalui lubang kecil dengan kedalaman $10 \mathrm{~mm}$. Setelah menetas, semua day old chick dipindahkan ke dalam pen $(1 \times 0,5 \times 0,5 \mathrm{~m})$ dengan alas litter sesuai dengan perlakuan telur sebelumnya. Hasil penelitian menunjukkan bahwa in-ovo feeding L-Arginine dapat meningkatkan bobot dan lingkar dada embrio, tapi tidak berpengaruh terhadap panjang embrio. In-ovo feeding L-Arginine menghasilkan pertambahan bobot badan yang lebih tinggi dan konversi pakan yang lebih rendah, serta konsumsi pakan yang tidak berbeda dibadingkan dengan kontrol. Performa tingkat pertumbuhan pada pemeliharaan di atas 6 minggu nyata meningkat dengan meningkatnya pemberian L-Arginine sampai 1,0\%. Dapat disimpulkan bahwa perkembangan embrio dan performa ayam kampung setelah menetas nyata meningkat dengan in-ovo feeding L-Arginine.
\end{abstract}

Kata kunci: embrio, in-ovo feeding, asam amino, produktivitas, ayam kampung

*Corresponding author:

E-mail: muhammadazhar030390@gmail.com 


\section{INTRODUCTION}

Kampung chicken is one of native chicken breeds in Indonesia. It is mostly found in rural areas reared in conventional, semi intensive and full intensive systems. Compared with commercial breed, kampung chicken in their original habitat showed a better adaptability and disease resistance (Sulistyoningsih et al., 2013; Azahan et al., 2014; Tamzil et al., 2015), but lower performance as an animal-protein producer (meat and egg).

Muscle mass is an important indicator in determining body weight. Increased muscle mass has a very close correlation with the higher final body weight (Fernandes et al., 2009; Fouad et al., 2012). On the optimum environmental conditions such as nutrition, management, and climate, the number of muscle cells will be the determinant of muscle mass. Grodzik et al. (2013) reported that more muscle number is formed in the embryonic phase, and then more muscle cells will hypertrophy. These conditions will have an impact on the increasing of growth rate, so higher body weight can be achieved in a short time.

Change in the number of muscle cells in poultry is only occurred during the incubation period (embryonic development) (Guo-song et al., 2012; Grodzik et al., 2013). The number of muscle cells in this period will not be changed and only experienced magnification (hypertrophy) after passing through the embryonic phase. The level of growth hormone in the embryonic phase determines the activity of the cell proliferation (Fernandes et al., 2009; De Carvalho et al., 2012). Manipulation of growth hormone levels can be done by increasing the availability of nutrients for embryos, especially protein (Coskun et al., 2014). However, the chicken embryo development occurs outside the body and nutritional needs of embryos have been determined in the process of egg formation, so we need the right method to add exogenous nutrients into the egg.

In-ovo feeding is a technique of adding exogenous nutrition into eggs in the incubation period. In-ovo feeding was reported to increase the performance of chickens after hatching (Daneshyar et al., 2010; Kornasio et al., 2011; Chen et al., 2013; Shafey et al., 2014; Al-Shamery \& Al-Suhaib, 2015). This condition is believed to occur because of the optimal development of the embryo during embryogenesis.

L-Arginine is an amino acid that is classified as a semi-essential amino acid (Al-Daraji et al., 2012). Foye (2005) reported that the administration of L-Arginine in the embryonic phase could increase the growth rate of turkey after hatching, while Murakami et al. (2012) suggested that L-Arginine was an important stimulator of growth hormone release. Another study report that L-Arginine can increase muscle mass (Fernandes et al., 2009). In addition, L-Arginine is also a basic amino acid which has a major role as a stimulator of other amino acids like proline, ornithine, glutamine, and creatine (AlDaraji et al., 2012); as well as compounds that play important roles in the physiological activities of chicken such as nitric oxide, polyamines, and dimethylargininesa (Fouad et al., 2012).
Administration of L-Arginine at a dose of $0.7 \%$ in turkeys (Foye et al., 2006) and 1.0\% in quail (Al-Daraji et al., 2012) by in-ovo feeding could increase body weight and post-hatch performance. The present study was conducted to evaluate the effect of in-ovo feeding of L-Arginine on embryo development and post-hatch performance of kampung chicken.

\section{MATERIALS AND METHODS}

This research used 135 fertile eggs with an average weight range of 42-43 $\mathrm{g}$ which were obtained from 50 weeks of age hens kept in an intensive rearing system. All eggs were placed into a semi-automatic incubator with the temperature of $37.5-38.5^{\circ} \mathrm{C}$ and relative humidity of $\pm 65 \%$. The experimental eggs were arranged in a completely randomized design (CRD) with 5 treatments and 3 replications. Each replication consisted of nine eggs. From day 3 until 17 of the incubation period, the eggs were turned 3 times a day (at 07:00, 15:00, and 22:00). On day 7 of the incubation period, the eggs were checked for fertility. The infertile eggs were then replaced with fresh prepared fertile eggs.

In-ovo feeding was applied according to the design of 5 treatment groups. The first group was without injection (negative control), the $2^{\text {nd }}$ group was injected with saline solution of $0.9 \%$ (positive control), the $3^{\text {rd }}$ group was injected with $0.5 \%$ L-arginine $(0.5 \mathrm{~g}$ per 100 $\mathrm{mL}$ saline $\mathrm{m} / \mathrm{v})$, the $4^{\text {th }}$ group was injected with $1.0 \%$ L-arginine $(1.0 \mathrm{~g}$ per $100 \mathrm{~mL}$ saline $\mathrm{m} / \mathrm{v})$, and the $5^{\text {th }}$ group was injected with $1.5 \%$ L-arginine (1.5 g per 100 $\mathrm{mL}$ saline $\mathrm{m} / \mathrm{v}$ ). The material was injected into albumen $(0.5 \mathrm{~mL} / \mathrm{egg})$ on day 10 of the incubation period. Before being injected, the broad end of eggs was on the top position. The injection was carried out using an automatic syringe into the narrow end of the egg with the depth of $10 \mathrm{~mm}$ of the needle length. The injected area was cleaned with alcohol and covered using paraffin and nail paint. Then all eggs were returned back into the incubator.

After hatching, all day old chick (DOC) were placed in arranged floor pens (length $\mathrm{x}$ width $\mathrm{x}$ height $/ 1 \times 0.5$ $\mathrm{x} 0.5 \mathrm{~m}$ ) in accordance with the treatment arrangement. Each pen consists of 3 unsexed chickens. Each pen was equipped with 60 watt light bulb, a feeder, and a drinker. Feed (Table 1) and drinking water were provided ad libitum. Vitamin was given via the drinking water at the

Table 1. Nutrient content of feed (Crumble BP 11)

\begin{tabular}{lc}
\hline Nutrient & $(\%)^{*}$ \\
\hline Water & 13.0 \\
Protein & $21.0-23.0$ \\
Fat & 5.0 \\
Fiber & 5.0 \\
Ash & 7.0 \\
Calcium & 0.9 \\
Phosphors & 0.6 \\
\hline
\end{tabular}

* Note: Analysis by PT. Charoen Pokphand Indonesia. 
ages of $1,2,3,7,8$, and $9 \mathrm{~d}$, while antibiotics were given at the age of $4,5,6,15,16$, and $17 \mathrm{~d}$. At the age of $4^{\text {th }}$ day, the vaccination (ND live) was administered via eye drops.

The observation of embryo development begins with the breaking of eggs on day 18 of the incubation period (3 eggs per treatment in each replication). Variables measured were body weight, embryo length, and pectoral circumference of the embryo that were measured after the embryo was separated from the other components such as albumen, allantoin, amnion, and yolk sac. Post-hatch performance was evaluated by measuring variables of feed intake, body weight gain, and feed conversion efficiency. The growth rate was obtained by measuring the body weight of chicken at the ages of 1, 2, 3, 4, 5, and 6 weeks. Data were analyzed following the analysis of variance. If the treatment showed significant effect it was then continued to be tested with Duncan's multiple range test (Gaspersz, 1991).

\section{RESULTS}

In-ovo feeding of L-Arginine into kampung chicken eggs on day $10^{\text {th }}$ of incubation period significantly af- fected $(\mathrm{P}<0.05)$ embryo weight, pectoral circumference, body weight gain, feed conversion, and weekly body weight, but did not affect embryo length, and feed intake (Tables 2, 3, and 4). The results showed that inovo feeding of L-Arginine increased embryo weight, pectoral circumference, body weight gain, and feed conversion, and weekly body weight compared to control group. Negative and positive control treatments showed no significant effect on the variables measured.

\section{DISCUSSION}

In-ovo feeding of L-Arginine resulted in a higher embryo weight. The increasing of embryo weight may be due to the increase in muscle mass as it is affected by administration of in-ovo feeding. L-Arginine was reported as one of the amino acids that could stimulate muscle development (Zhao et al., 2011; Fu et al., 2016). Based on this report, we assumed that in-ovo feeding of L-Arginine increased L-Arginine content in the muscle and resulting the increased muscle mass and heavy embryo.

L-Arginine has been reported to increase growth hormone (Sahin et al., 2006; McKnight et al.,

Table 2. Embryo development of in-ovo feeding of L-Arginine kampung chickens on day 18 of incubation period

\begin{tabular}{lccccc}
\hline \multirow{2}{*}{\multicolumn{1}{c}{ Variables }} & \multicolumn{5}{c}{ In-ovo feeding } \\
\cline { 2 - 6 } & Negative control & Positive control & L-Arginine $0.5^{\mathrm{o}}$ & L-Arginine $1.0 \%$ & L-Arginine $1.5 \%$ \\
\hline Embryo weight $(\mathrm{g})$ & $14.13 \pm 0.35^{\mathrm{a}}$ & $15.03 \pm 2.75^{\mathrm{a}}$ & $19.56 \pm 0.43^{\mathrm{b}}$ & $18.58 \pm 2.49^{\mathrm{b}}$ & $18.78 \pm 0.87^{\mathrm{b}}$ \\
Embryo length $(\mathrm{cm})$ & $7.42 \pm 0.02$ & $7.65 \pm 0.45$ & $8.22 \pm 0.15$ & $8.23 \pm 0.38$ & $7.83 \pm 0.54$ \\
Pectoral circumference $(\mathrm{cm})$ & $5.00 \pm 0.30^{\mathrm{a}}$ & $5.20 \pm 0.20^{\mathrm{ab}}$ & $5.64 \pm 0.05^{\mathrm{c}}$ & $5.53 \pm 0.09^{\mathrm{bc}}$ & $5.52 \pm 0.06^{\mathrm{bc}}$ \\
\hline
\end{tabular}

Note: Means in the same rows with different superscripts differ significantly $(\mathrm{P}<0.05)$.

Table 3. Post-hatch performance of in-ovo feeding of L-Arginine kampung chickens at the age of 42 days

\begin{tabular}{lccccc}
\hline \multirow{2}{*}{ Variables } & \multicolumn{5}{c}{ In-ovo feeding } \\
\cline { 2 - 6 } & Negative control & Positive control & L-Arginine $0.5 \%$ & L-Arginine $1.0 \%$ & L-Arginine $1.5 \%$ \\
\hline Feed intake $(\mathrm{g} /$ bird) & $1127.16 \pm 37.40$ & $1118.73 \pm 7.80$ & $1140.98 \pm 14.20$ & $1137.52 \pm 2.10$ & $1131.80 \pm 7.20$ \\
Body weight gain $(\mathrm{g} / \mathrm{bird})$ & $515.46 \pm 16.40^{\mathrm{a}}$ & $511.47 \pm 17.20^{\mathrm{a}}$ & $565.15 \pm 15.50^{\mathrm{b}}$ & $617.44 \pm 11.50^{\mathrm{c}}$ & $604.51 \pm 12.60^{\mathrm{c}}$ \\
Feed conversion & $2.19 \pm 0.08^{\mathrm{c}}$ & $2.17 \pm 0.07^{\mathrm{c}}$ & $2.02 \pm 0.08^{\mathrm{b}}$ & $1.84 \pm 0.04^{\mathrm{a}}$ & $1.87 \pm 0.02^{\mathrm{a}}$ \\
\hline
\end{tabular}

Note: Means in the same rows with different superscripts differ significantly $(\mathrm{P}<0.05)$.

Table 4. The average weekly body weight of kampung chicken post in-ovo feeding of L-Arginine (g/bird)

\begin{tabular}{cccccc}
\hline \multirow{2}{*}{ Week } & \multicolumn{5}{c}{ In-ovo feeding } \\
\cline { 2 - 6 } & Negative control & Positive control & L-Arginine $0.5^{\mathrm{o}}$ & L-Arginine $1.0 \%$ & L-Arginine $1.5^{\circ} \%$ \\
\hline I & $66.15 \pm 0.42^{\mathrm{a}}$ & $64.87 \pm 0.89^{\mathrm{a}}$ & $70.40 \pm 1.31^{\mathrm{b}}$ & $70.33 \pm 0.977^{\mathrm{b}}$ & $71.00 \pm 0.08^{\mathrm{b}}$ \\
II & $124.48 \pm 4.52^{\mathrm{ab}}$ & $122.72 \pm 4.73^{\mathrm{a}}$ & $131.27 \pm 5.12^{\mathrm{bc}}$ & $134.52 \pm 4.69^{\mathrm{c}}$ & $135.18 \pm 2.56^{\mathrm{c}}$ \\
III & $201.75 \pm 2.64^{\mathrm{a}}$ & $200.00 \pm 3.42^{\mathrm{a}}$ & $220.40 \pm 6.17^{\mathrm{b}}$ & $215.50 \pm 8.51^{\mathrm{b}}$ & $221.75 \pm 6.24^{\mathrm{b}}$ \\
IV & $286.86 \pm 3.52^{\mathrm{a}}$ & $290.20 \pm 3.96^{\mathrm{a}}$ & $310.45 \pm 12.98^{\mathrm{b}}$ & $322.05 \pm 7.35^{\mathrm{b}}$ & $315.32 \pm 11.20^{\mathrm{b}}$ \\
V & $396.88 \pm 9.66^{\mathrm{a}}$ & $405.91 \pm 13.32^{\mathrm{a}}$ & $427.53 \pm 5.52^{\mathrm{b}}$ & $459.48 \pm 9.86^{\mathrm{c}}$ & $450.65 \pm 10.35^{\mathrm{c}}$ \\
VI & $542.14 \pm 16.34^{\mathrm{a}}$ & $542.13 \pm 17.40^{\mathrm{a}}$ & $594.21 \pm 14.82^{\mathrm{b}}$ & $647.27 \pm 12.07^{\mathrm{c}}$ & $633.73 \pm 12.39^{\mathrm{c}}$ \\
\hline
\end{tabular}

Note: Means in the same rows with different superscripts differ significantly $(\mathrm{P}<0.05)$. 
2010; Murakami et al., 2012) and insulin (Foye, 2005; Fernandes et al., 2009; Silva et al., 2012). L-Arginine could increase growth hormone by GH/IGF signaling pathway. The increase in growth hormone caused the increased organogenesis activity such as proliferation, differentiation, and maturation of cells (Deprem \& Gulmez, 2007; Daneshyar et al., 2010).

Averages feed intakes of all treatments were not significantly different. This may occur due to the type and form of feed used in all treatments were similar, therefore the feed palatability was not different. This level of palatability proved that the feed intake did not differ.

The value of feed conversion showed a decrease with higher concentrations of L-arginine. Injection of L-arginine about $1.0 \%$ and $1.5 \%$ resulted in lower feed conversion ratio than the other treatments. Group of chicken with a lower feed conversion ratio showed an improvement of digestive tract performance as might be influenced by the L-Arginine administration. Therefore, the absorption of nutrients was more effective and impact on the derivation of feed conversion. Similar results were also reported by Foye et al. (2009) on turkeys, AlDaraji et al. (2012) on quail, and De Carvalho et al. (2012) on laying hens.

As reported by Fouad et al. (2012), L-Arginine stimulated cell proliferation of small intestine. Increasing L-arginine levels in the embryonic phase would lead to an increase in the number of small intestine cells (Lin et al., 2011). Tako et al. (2004) and Cheled-Shoval et al. (2011) explained that an increase in the size of the villi and crypts were the result of the increase in the number of cells because proliferation activities of the small intestine were high at the beginning of growth. Increasing the size of the villi and crypts will lead to an increase in the surface area of the small intestine (Foye, 2005). This increase caused an increase in nutrient absorption. While Smirnov et al. (2006) and Ospina-Rojas et al. (2013) explained that the increasing of the surface area of small intestine was the result of the increased mucin gene expression by goblet cells.

Although the injection of L-Arginine resulted in a higher body weight, at the early week of rearing period, different concentrations of L-Arginine that were injected did not affect body weight. However, at the late weeks of the rearing period, chicken injected with the higher dose of L-Arginine had the higher body weight. This condition indicated that the higher concentration of L-Arginine injected resulted the higher number of muscle cells.

Changes in the number of muscle cells is actually not directly influenced by L-Arginine. L-Arginine is a stimulator of IGFs which will work as a stimulator of proliferation activity of muscle cells in the embryonic phase. Therefore, L-Arginine stimulates the production of IGFs (IGF-1 and IGF-2) through the mechanism of GH/IGFs axis (Fernandes et al., 2009; Hazim et al., 2012). The increasing levels of IGFs is caused by the increased sensitivity of hormone receptors in the mechanism of GH/IGFs axis by L-Arginine (Foye et al., 2009; De Carvalho et al., 2012). While Fouad et al. (2012) reported that Arginine was an essential raw material in the chemical structure of IGFs. Increasing levels of IGFs on embryonic phase would inhibit the activity of myostatin and activate the MAP kinase pathway (Kollias \& McDermott, 2008). MAP kinase pathway activity causes cell proliferation process for a long time.

\section{CONCLUSION}

In-ovo feeding of L-Arginine increased embryo development of kampung chicken. Injection of $1.0 \%$ concentration of L-Arginine in-ovo increased post-hatch performances and growth rate.

\section{ACKNOWLEDGEMENT}

This research was supported by LPDP (Thesis and Dissertation Scholarship), and we expressed appreciation for the technical assistance by Rahmawati and Nasrum in the Faculty of Animal Agriculture, Hasanuddin University.

\section{REFERENCES}

Al-Daraji, H. J. \& A. M. Salih. 2012. The influence of dietary arginine supplementation on blood traits of broiler chickens. Pakistan Journal of Nutrition 11:258-264. http://dx.doi. org/10.3923/pjn.2012.258.264

Al-Daraji, H. J., A. A. Al-Mashadani, W. K. Al-Hayani, A. S. Al-Hassani, \& H. A. Mirza. 2012. Effect of in-ovo injection with L-arginine on productive and physiological traits of Japanese quail. South African Journal of Animal Science, 42:139-145. http://dx.doi.org/10.4314/sajas.v42i2.6

Al-Shamery, N. J. \& M. B. S. Al-Shuhaib. 2015. Effect of in-ovo injection of various nutrients on the hatchability, mortality ratio and weight of the broiler chickens. IOSR Journal of Agriculture and Veterinary Science 8:30-33.

Azahan, E. A. E., I. A. Azma, \& M. Noraziah. 2014, Effects of strain, sex and age on growth performance of malaysian kampong chickens. Malaysian Journal Animal Science 17:27-33.

Bhanja, S. K. \& A. B. Mandal. 2005. Effect of in-ovoinjection of critical amino acids on pre- and post-hatch growth, immunocompetence and developmentof digestive organs in broiler chickens. Asian-Australas. J. Anim. Sci. 18:524-531. http://dx.doi.org/10.5713/ajas.2005.524

Cheled-Shoval, S. L., E. Amit-Romach, M. Barbakov, \& Z. Uni. 2011. The effect of in ovo administration of mannan oligosaccharide on small intestine development during the preand posthatch periods in chickens. Poultry Sci. 90:23012310. http://dx.doi.org/10.3382/ps.2011-01488

Chen, W., M. Tangara, J. Xu, \& J. Peng. 2012. Developmental transition of pectoralis muscle from atrophy in late-term duck embryos to hypertrophy in neonates. Experimental Physiology 97:861-872. http://dx.doi.org/10.1113/ expphysiol.2011.01083.x

Chen, W., Y. T. Lv, H. X. Zhang, D. Ruan, S. Wang, \& Y. C. Lin. 2013. Review: Developmental specificity in skeletal muscle of late-term avian embryos and its potential manipulation. Poultry Sci. 92:2754-2764. http://dx.doi.org/10.3382/ ps.2013-03099

Coşkun, I., H. Çayan, Ö. Yilmaz, A. Taskin, E. Tahtabiçen, \& H. E. Samli. 2014. Effects of in-ovo pollen extract injection to fertile broiler eggs on hatchability and subsequent chick weight. Türk Tarım ve Doğa Bilimleri Dergisi 1:485-489.

Daneshyar, M., J. M. C. Geuns, J. G. Buyse, H. Kermanshahi, H. Willemsen, Z. Ansari, E. Decuypere, \& N. Everaert. 2010. 
Evaluation of steviol injection on chicken embryo: effect on post-hatch development, proportional organ weight, plasma thyroid hormone and metabolites. Journal Poultry Science 47:71-76. http://dx.doi.org/10.2141/jpsa.009059

De Carvalho, F. B., J. H. Stringhini, M. S. Matos, R. M. J. Filho, M. B. Café, N. S. M. Leandro, \& M. A. Andrade. 2012. Performance and nitrogen balance of laying hens fed increasing levels of digestible lysine and arginine. Revista Brasileira de Zootecnia, 41:2183-2188. http://dx.doi. org/10.1590/S1516-35982012001000007

Deprem, T. \& N. Gulmez. 2007. The effects of in-ovo insulin-like growth factor-1 on embryonic development of musculus longus colli dorsalis in japanese quail. Turkish Journalof Veterinary and Animal Science, 31:233-240.

Fernandes, J.I.M., A.E. Murakami, E.N. Martins, M.I. Sakamoto, and E.R.M. Garcia. 2009. Effect of arginine on the development of the pectoralis muscle and the diameter and the protein: deoxyribonucleic acid rate of its skeletal myofibers in broilers. Poultry Sci. 88:1399-1406. http:// dx.doi.org/10.3382/ps.2008-00214

Fouad, A. A., H. K. El-Senousey, X. J. Yang, \& J. H. Yao. 2012. Role of dietary 1- arginine in poultry production. International Journal of Poultry Science 11: 718-729. http:// dx.doi.org/10.3923/ijps.2012.718.729

Foye, O. T. 2005. The biochemical and molecular effects of amnionic nutrient administration, "in-ovo feeding" on intestinal development and function and carbohydrate metabolism in turkey embryos and poults. Dissertation. Graduate Faculty of North Carolina State University.

Foye, O. T., C. Ashwell, Z. Uni, \& P. R. Ferket. 2009. The effects of intra-amnionic feeding of arginine and/or $B$ hyroxy- $B$-methylbutyrate on jejunal gene expression in the turkey embryo and hatchling. International Journal of Poultry Science 8:437-445. http://dx.doi.org/10.3923/ ijps.2009.437.445

Foye, O. T., Z. Uni , J. P. McMurtry, \& P. R. Ferket. 2006. The effects of amniotic nutrient administration, "in-ovo feeding" of arginine and/or ß-hydroxy-ß-methyl butyrate (HMB) on insulin-like growth factors, energy metabolism and growth in turkey poults. International Journal of Poultry Science 5:309-317. http://dx.doi.org/10.3923/ijps.2006.309.317

Fu, Q., Z. X. Leng, L. R. Ding, T. Wang, C. Wen, \& Y. M. Zhou. 2016. Complete replacement of supplemental DLmethionine by betaine affects meat quality and amino acid contents in broilers. Anim. Feed Sci. Technol. 212:6369.http://dx.doi.org/10.1016/j.anifeedsci.2015.12.004

Gasperz, V. 1991. Metode Perancangan Percobaan. Armico, Bandung.

Grodzik, M., F. Sawosz, E. Sawosz, A. Hotowy, M. Wierzbicki, M. Kutwin, S. Jaworski, \& A. Chwalibog. 2013. Nanonutrition of chicken embryos. The effect of in-ovo administration of diamond nanoparticles and l-glutamine on molecular responses in chicken embryo pectoral muscles. International Journal of Molecular Science 14:23033-23044. http://dx.doi.org/10.3390/ijms141123033

Guo-song, W., L. He-he, L. Lin-seng, \& W. Ji-wen. 2012. Influence of ovo injecting igf- 1 on weights of embryo, heart and liver of duck during hatching stages. International Journal of Poultry Science 11:756-760. http://dx.doi. org/10.3923/ijps.2012.756.760

Kollias, H. D. \& J. C. McDermott. 2008. Transforming growth factor- $\beta$ and myostatin signaling in skeletal muscle. Journal of Applied Physiology 104:579-587. http://dx.doi. org/10.1152/japplphysiol.01091.2007
Kornasio, R., O. Halevy, O. Kedar, \& Z. Uni. 2011. Effect of in-ovo feeding and its interaction with timing of first feed on glycogen reserves, muscle growth, and body weight. Poultry Sci. 90:1467-1477. http://dx.doi.org/10.3382/ ps.2010-01080

Lin, H., J. Zong-yong, L. Yin-cai Lin, Z. Chun-tian, W. Shi-kui, Y. Xue-feng, and W. Guo-yao. 2011. Effects of L-arginine on intestinal development and endogenous argininesynthesizing enzymes in neonatal pigs. African Journal of Biotechnology 10:7915-7925. http://dx.doi.org/10.5897/ AJB11.1180

McKnight, J. R., M. C. Satterfield, W. S. Jobgen, S. B. Smith, T. E. Spencer, C. J. eininger, C. J. McNeal, \& G. Wu. 2010. Beneficial effects ofL-arginine on reducing obesity: potential mechanisms and important implications for human health. Amino Acids 39:349-357. http://dx.doi.org/10.1007/ s00726-010-0598-z

Murakami, A.E.,J.I.M.Fernandes, L.Hernandes, \& T.C. Santos. 2012. Effects of starter diet supplementation with arginine on broiler production performance and on small intestine morphometry. Pesquisa Veterinaria Brasileira 32:259-266. http://dx.doi.org/10.1590/S0100-736X2012000300014

Ospina-Rojas, I. C., A. E. Murakami, C. A. L. Oliveira, \& A. F. Q. G. Guerra. 2013. Supplemental glycine and threonine effects on performance, intestinal mucosa development, and nutrient utilization of growing broiler chickens. Poultry Sci. 92:2724-2731. http://dx.doi.org/10.3382/ ps.2013-03171

Sahin, K., M. Onderci, N. Sahin, T. A. Balci, M. F. Gursu, V. Juturu, \& O. Kucuk. 2006. Dietary arginine silicate inositol complex improves bone mineralization in quail. Poultry Sci. 85:486-492. http://dx.doi.org/10.1093/ps/85.3.486

Shafey, T. M., A. H. Mahmoud, A. A. Alsobayel, \& M. A. Abouheif. 2014. Effects of in ovo administration of amino acids on hatchability and performance of meat chickens. South African Journal of Animal Science 44:123-130. http:// dx.doi.org/10.4314/sajas.v44i2.4

Silva, L. M. G. S., A. E. Murakami, J. I. M. Fernandes, D. D. Rosa, \& J. F. Urgnani. 2012. Effects of dietary arginine supplementation on broiler breeder egg production and hatchability. Brazilian Journal of Poultry Science 14:233-304.

Smirnov, A., E. Tako, P. R. Ferket, \& Z. Uni. 2006. Mucin gene expression and mucin content in the chicken intestinal goblet cells are affected by in-ovo feeding of carbohydrates. Poultry Sci. 85:669-673. http://dx.doi.org/10.1093/ ps/85.4.669

Sulistyoningsih, M., D. Sunarti, E. Suprijatna, \& Isroli. 2013, Performance of indigenous chicken under intensive rearing with various litter materials. International Journal of Science and Engineering 4:52-56. http://dx.doi. org/10.12777/ijse.4.2.2013.52-56

Tako, E., P. R. Ferket, \& Z. Uni. 2004. Effects of in-ovo feeding of carbohydrates and $\beta$-hydroxy- $\beta$-methylbutyrate on the development of chicken intestine. Poultry Sci. 83:20232028. http://dx.doi.org/10.1093/ps/83.12.2023

Tamzil, M. H., M. Ichsan, N. S. Jaya, \& M. Taqiuddin. 2015, Growth rate, carcass weight and percentage weight of carcass parts of laying type cockerels, kampong chicken and arabic chicken in different ages. Pakistan Journal of Nutrition 14:377-382. http://dx.doi.org/10.3923/ pjn.2015.377.382

Zhao, G. P., H. X. Cui, R. R. Liu, M. Q. Zheng, J. L. Chen, \& J. Wen. 2011. Comparison of breast muscle meat quality in 2 broiler breeds. Poultry Sci. 90:2355- 2359. http://dx.doi. org/10.3382/ps.2011-01432 